\title{
Image Processing untuk Deteksi Objek pada Daerah Bencana
}

\author{
Arif Ainur Rafiq ${ }^{1 *}$ Sugeng Dwi Riyanto ${ }^{2}$ Bagas Dwi Aprilas $^{3}$, Rizki Priya Pratama ${ }^{4}$ \\ ${ }^{1,2,3}$ Program Studi Teknik Elektronika, Jurusan Teknik Elektro, Politeknik Negeri Cilacap \\ ${ }^{4}$ Jurusan Teknik Mekatronika, Politeknik Kota Malang \\ *e-mail: arifainurrafiq@gmail.com
}

\begin{abstract}
Abstrak - Pencarian korban pasca terjadinya bencana alam menjadi faktor yang sangat penting untuk dilakukan. Objek yang mayoritas diperhatikan adalah manusia. Cepat tanggapnya penanganan hal tersebut juga dipengaruhi banyak faktor, salah satunya adalah medan yang rumit dan terisolasi sehingga aksesnya terbatas sehingga banyak korban yang tidak dapat ditangani dalam waktu yang cepat. Jalur udara merupakan alternatif yang dapat dimanfaatkan, yaitu menggunakan Quadcopter yang memungkinkan untuk memantau kondisi lokasi bencana alam melalui kamera sebagai pendeteksi objek menggunakan pengolahan citra dengan kontroler Raspberry Pi 3. Kendali Ardupilot Mega 2.8 terintegrasi dengan Mission Planner sebagai Ground Control Station (GCS) melalui telemetri. Pengujian menghasilkan data image yang didapatkan dengan jarak 1-meter hingga 6-meter dari objek dengan kemampuan mengirimkan data ke GCS sejauh 45 meter.
\end{abstract}

Kata Kunci : Quadcopter, Raspberry Pi 3, Mission Planner

\begin{abstract}
The search for victims after natural disasters is a very important factor. The object majority concern is humans. The quick responsiveness of handling is influenced by many factors, which are complicated terrain, isolated areas, limited access, so that many victims cannot be dealt quickly. Air transportation is an alternative that can be utilized using a quadcopter to monitor the condition of the location of natural disasters through the camera as an object detection using image processing with Raspberry Pi 3. Arduino Mega 2.8 is used as an integrated control with Mission Planner as Ground Control Station (GCS) through telemetry. The image from the camera is obtained with a distance of 1 meter to 6 meters from the object with the ability to send data to GCS with a distance of 45 meters.
\end{abstract}

Key words: Quadcopter, Raspberry Pi 3, Mission Planner

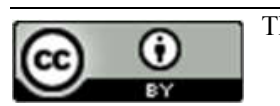

This is an open access article distributed under the Creative Commons 4.0 Attribution License

\section{Pendahuluan}

Bencana alam merupakan suatu peristiwa alam yang berdampak pada manusia dan bumi itu sendiri. Indonesia sebagai negara yang rawan terhadap bencana, jenis bencana alam yang sering terjadi di Indonesia adalah jenis bencana alam meteorologi yang berhubungan dengan iklim seperti banjir, kekeringan, dan bencana alam yang terjadi pada permukaan bumi (geologi) seperti gempa bumi, gunung meletus, dan tanah longsor. Dampak yang ditimbulkan oleh bencana tersebut sangat merugikan bagi masyarakat sekitarnya. Selain kerugian materi, seringkali proses evakuasi atau pencarian korban juga memerlukan waktu yang lama karena keadaan lokasi bencana yang susah diakses [1]. Untuk mencegah terjadinya kerugian maka diperlukan upaya seperti pencegahan, mitigasi, kesiapan dan peringatan dini. Namun saat bencana sudah terjadi, penanggulangan bencana tanggap darurat seperti evakuasi korban harus segera dilaksanakan.

Dalam prosesnya, evakuasi dan pemantauan lokasi bencana dapat dilakukan melalui jalur darat dan udara. Melalui jalur darat, biasanya menggunakan alat berat serta bantuan dari sukarelawan. Namun resiko yang dihadapi cukup banyak seperti jalur yang susah diakses, dan kemungkinan bertambahnya korban dari tim evakuasi. Sedangkan melalui jalur udara, biasanya menggunakan bantuan helikopter untuk menyisir lokasi bencana. Namun helikopter membutuhkan landasan khusus sebagai tempat mendarat, dan 
tidak bisa melakukan penyisiran secara maksimal karena ukurannya yang relatif besar dan rentan terhadap benturan. Sehingga diperlukan suatu alat pemantau yang memiliki kemampuan seperti helikopter, namun bahkan mampu terbang lebih rendah sehingga evakuasi dapat dilakukan dengan lebih efisien. Salah satu alat pemantau yang bisa digunakan adalah quadcopter.

Nilai yang dikedepankan dalam artikel ini ialah tepat gunanya pemanfaatan kecanggihan teknologi robot dalam membantu manusia di kondisi-kondisi medan yang sulit dan berbahaya. Efektivitas dalam kegiatan penyelamatan nyawa manusia, dimana korban bencana alam diharapkan dapat lebih cepat ditemukan serta mengurangi resiko bagi tim SAR sendiri serta efisiensi biaya dalam kegiatan pencarian korban, dimana kondisi yang membutuhkan operasional helikopter untuk melakukan scanning dari udara dapat digantikan dengan opersionalisasi robot terbang berkamera yang jauh lebih murah biaya operasionalnya.

\section{A. Quadcopter}

Merupakan salah satu jenis dari Vertical Takeoff Landing (VTOL) Aircraft, sehingga memungkinkan pesawar dapat melakukan take off dan landing secara tegak lurus terhadap posisi bumi. Quadcopter memiliki empat motor yang dilengkapi dengan empat propeller [2].

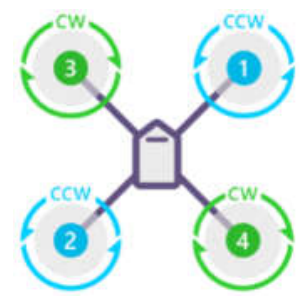

Gambar 1. Arah Putaran Baling-baling Pada Quadcopter

Berikut adalah konfigurasi Gerakan dasar pada quadcopter secara umum

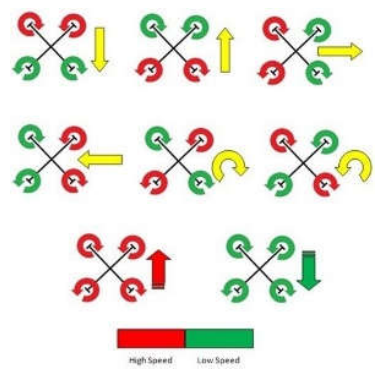

Gambar 2. Gerakan Dasar Quadcopter Berdasarkan Kecepatan Motor

\section{B. Frame}

Pada artikel ini menggunakan kerangka tipe DJI F450[3].

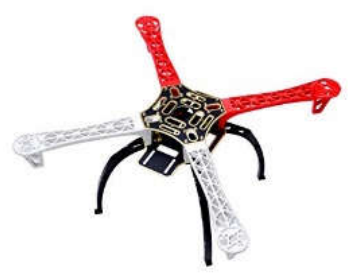

Gambar 3. Frame Tipe DJI F450 Quadcopter

\section{Flight Controller}

Merupakan komponen kontroler utama pada quadcopter [3]. Digunakan Arduino dengan tipe Ardupilot Mega [4][5].

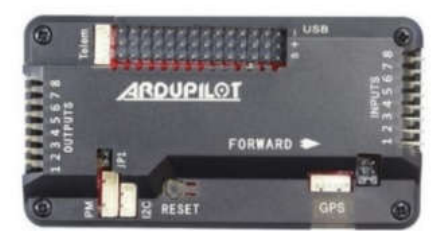

Gambar 4. ArduPilot Mega 2.8

\section{Motor Brushless}

Merupakan motor yang digunakan sebagai penggerak untuk quadcopter [6]. Pada artikel ini digunakan motor brushless $2212-920 \mathrm{kV}$.

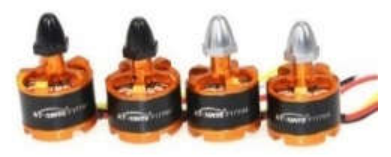

Gambar 5. Motor Brushless CW dan CCW 2212$920 \mathrm{kV}$

\section{E. Electronic Speed Controller (ESC)}

Merupakan device pada quadcopter yang memiliki fungsi sebagai driver motor brushless. Pada umumnya, satu unit ESC digunakan untuk men-drive satu unit aktuator (dalam hal ini adalah motor brushless). Pada penelitian ini menggunakan ESC Simonk 30A seperti pada Gambar 6.

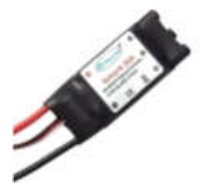

Gambar 6. ESC Simonk 30A

\section{F. Telemetri}

Telemetri merupakan teknologi untuk melakukan pengukuran dari jarak jauh dan memberikan informasi kepada usernya [7]. Dalam hal ini ada penyampaian informasi dari quadcopter kepada pengguna informasi tersebut [8]. 


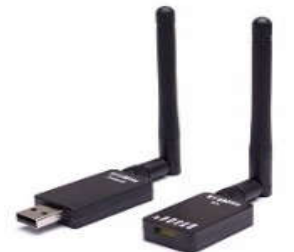

Gambar 7. Telemetri $433 \mathrm{MHz}$

\section{G. Mission Planner}

Merupakan perangkat lunak pendukung untuk ArduPilot Mega (Gambar 4) [9]. Software ini berfungsi untuk merencanakan misi yang akan dilakukan dan untuk upload firmware terbaru. Pada implementasi ini digunakan untuk melihat status dari aktivitas Gerakan quadcopter yaitu ketinggian terbang, jalur terbang yang sudah ditentukan, kondisi dan parameter lainnya secara real time [10].

\section{H. GPS Module}

Merupakan suatu modul yang berfungsi untuk mendeteksi lokasi dari quadcopter dan memproses sinyal dari satelit navigasi yang ada. Pada artikel ini pemanfaatan modul GPS digunakan untuk membuat sistem navigasi dan untuk tracking lokasi bencana yang terjadi [11].

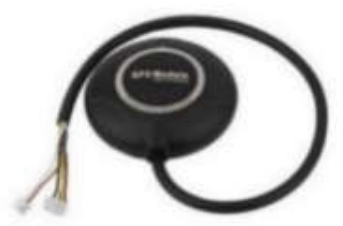

Gambar 8. GPS Module Ublox-Neo M8N

\section{Raspberry Pi 3 Model B}

Suatu perangkat berbentuk computer mini yang digunakan sebagai kontroler [12]. Memiliki RAM $1 \mathrm{~GB}, \mathrm{CPU}$ A 1.2GHx 64-bit quad-core ARMv8, Wireless LAN, Bluetooth 4.1 yang memiliki kemampuan Low Energy (BLE) [13].

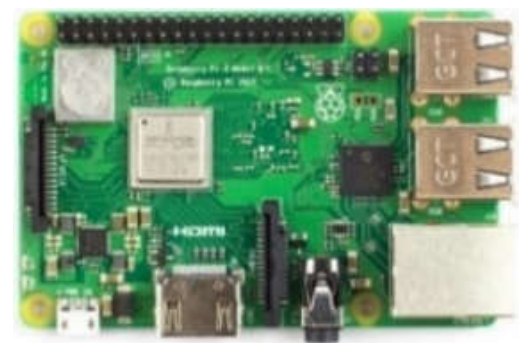

Gambar 9. Raspberry Pi 3 Model B

\section{J. Webcam}

Merupakan perangkat multimedia yang terdiri dari kamera untuk mengabadikan citra/gambar dan memiliki kemampuan sebagai perekam suara. Sehingga webcam dapat melakukan video view, video capture, dan video save [14]. Pada pendeteksi objek di-capture webcam Logitech C310 (Gambar 14) dengan resolusi layar $1280 \mathrm{x}$ 720 piksel, autofocus dan dapat mengambil gambar hingga lima megapiksel [15].

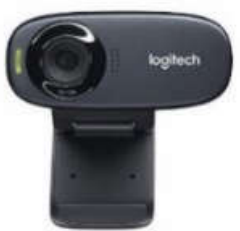

Gambar 10. Webcam Logitech C310

\section{METODE}

\section{A. Perancangan Sistem}

Dalam artikel ini, keseluruhan sistem dideskripsikan dalam bentuk diagram blok. Hal ini untuk memberikan gambaran terhadap pola kerja atau algoritma dari sistem secara keseluruhan.

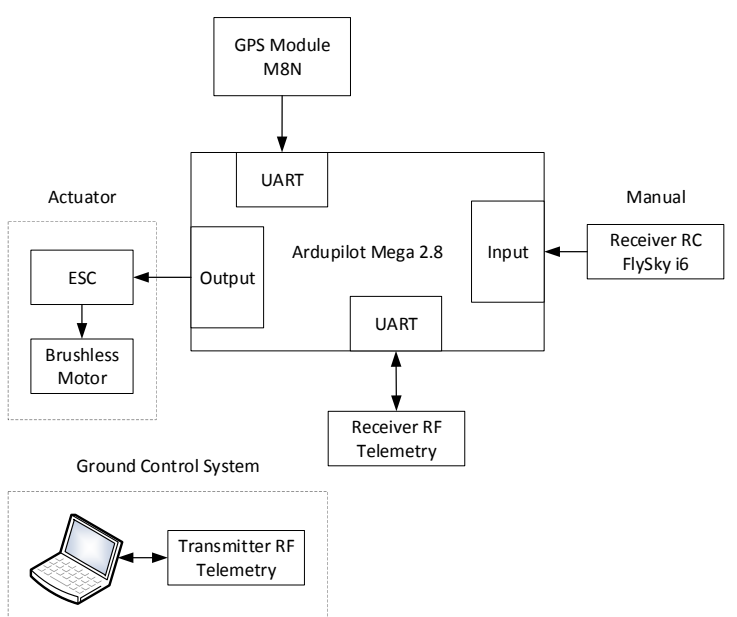

Gambar 11. Diagram Blok Quadcopter

Gambar 11 merupakan blok diagram sistem dari quadcopter, komponen yang terdapat di dalamnya adalah pengendali remote control, Flight Controller, ESC, Brushless Motor, Propeller, Telemetry, dan GPS Module. Data yang akan diterima oleh receiver diubah menjadi sinyal 4 channel dan ArduPilot Mega 2.8 melalui pin 1 sampai pin 4 sebagai input. GPS Module M $8 N$ dan telemetry dihubungkan ArduPilot Mega $2.8 \mathrm{ke}$ masing-masing port yang tersedia. Pada output ArduPilot Mega 2.8 untuk ESC menggunakan output pin 1 sampai pin 4 [16].

Gambar 12 merupakan blok diagram sistem dari image processing, yang terdiri dari Webcam dan Raspberry Pi 3 model B. Objek akan dideteksi oleh Webcam yang dihubungkan Raspberry Pi 3 melalui 
USB connection. Pada output akan diketahui melalui interface software yang digunakan.

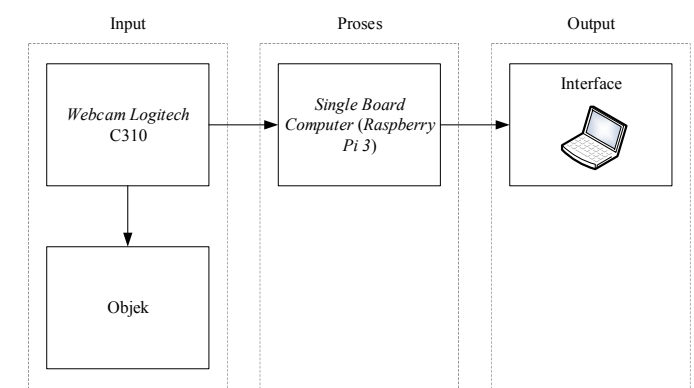

Gambar 12. Diagram Blok Image Processing

Gambar 13 merupakan flowchart dari Gerakan quadcopter. Dimulai dengan proses inisialisasi dan deklarasi terhadap sensor gyro, pengaturan pada receiver, level baterai hingga kalibrasi komponen ECS.

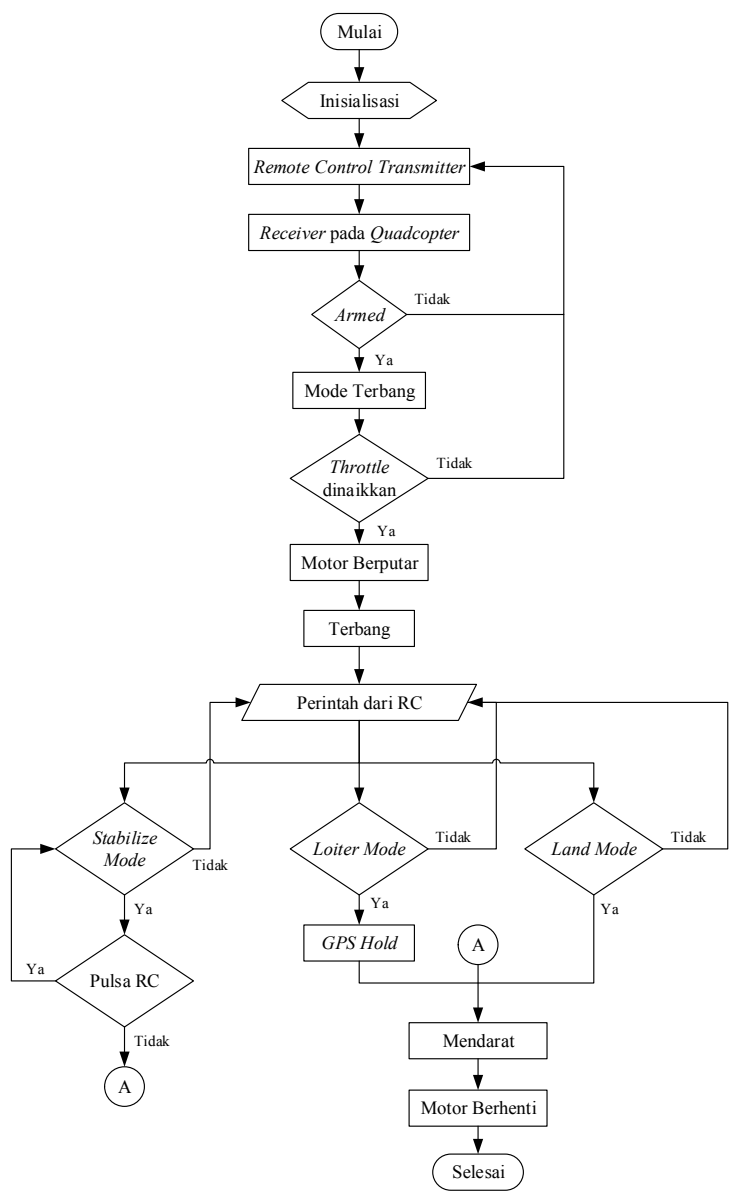

Gambar 13. Flowchart Quadcopter

Kemudian beberapa pengaturan saat pengabilan keputusan, receiver akan memberikan data sebagai berikut:

- Flight controller siap untuk terbang jika nilai throttle $=0$ PWM, yaw $=0$ PWM
- $\quad$ Program akan mengulang hingga throttle $=0$ jika nilai throttle $\neq 0$ PWM

- Nilai PWM dan yaw =0 PWM

Mode terbang quadcopter sesuai perintah dari $\mathrm{RC}$ akan terus dibaca, instruksi tersebut akan terus dijalankan hingga berubah pada mode Stabilize, yaitu quadcopter bergerak naik dan turun, manuver maju dan mundur, manuver kanan dan kiri, hingga gerakan berputar kanan dan kiri.

Pada mode Loiter, quadcopter mengunci lokasi dengan nilai minimum satelit GPS yaitu 3. Setelah melakukan mode ini, quadcopter tidak dapat digerakan kanan-kiri dan maju-mundur. Pada mode Land, quadcopter secara otomatis mengurangi kecepatan putaran motor1, motor2, motor3, dan motor4 secara merata sampai bagian fisik terbawah quadcopter menyentuh tanah kemudian motor akan berhenti.

Jika nilai throttle $=0$ pada mode Stabilize dan Loiter maka quadcopter secara manual akan turun ke bawah dan motor berhenti.

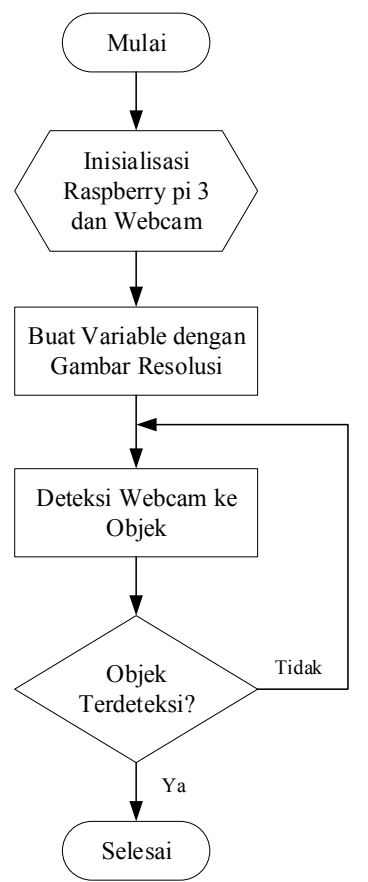

Gambar 14. Flowchart Image Processing

Pada Gambar 14, sistem on kemudian melakukan inisialisasi webcam yang dikoneksikan dengan raspberry pi 3 untuk mendeteksi objek. Foto pada setiap objek dapat dilihat perbedaan sesuai variabel yang ditentukan. Jika objek terdeteksi maka sistem akan selesai, sedangkan jika tidak maka proses deteksi akan terlanjut. Pengaturan resolusi gambar dan faktor pencahayaan akan memberikan kualitas terhadap image yang diambil oleh kamera. 


\section{B. Perancangan Perangkat Keras}

Pada tahap ini teradapat beberapa langkah yang dikerjakan yaitu: mekanisme gerakan quadcopter, desain rangkaian (schematic) dan mekanik yang digunakan.

\section{1) Perancangan Rangkaian}

Perancangan rangkaian dilakukan untuk memastikan bahwa semua komponen yang dibutuhkan dapat tersusun dan terangkai seluruhnya, sesuai dengan fungsinya.

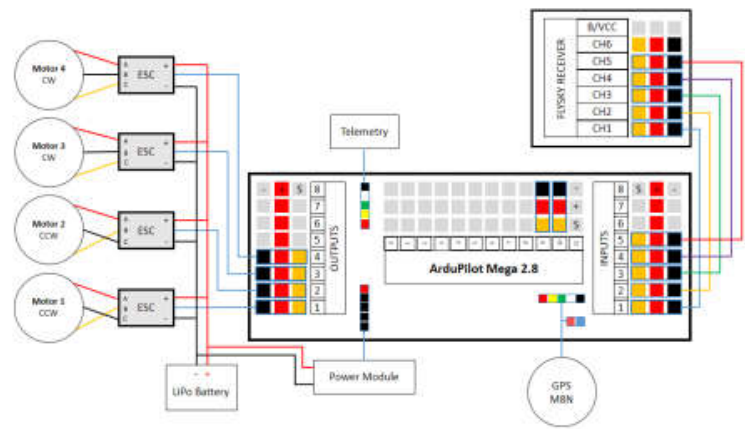

Gambar 15. Rangkaian Quadcopter

\section{2) Perancangan Gerak Quadcopter}

Setiap channel mempunyai fungsi sebagai penggerak quadcopter pada saat terbang di udara, sebagai berikut:

a) Gerak Pitch

Untuk melakukan gerak maju dan gerak mundur dengan kendali RC pada channel 2 .

b) Gerak Roll

Untuk melakukan maneuver ke arah kanan dan arah kiri. Digunakan channel 1 pada RC.

c) Gerak Yaw

Gerakan quadcopter untuk bergerak putar. Pada RC digunakan channel 4 untuk mengendalikannya.

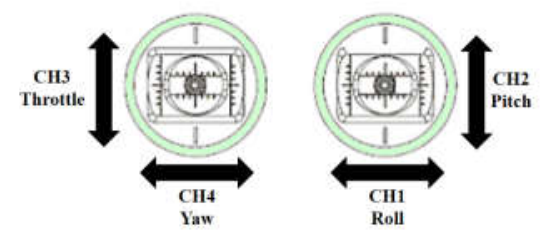

Gambar 16. Channel Gerak Robot

\section{3) Perancangan Desain Mekanik}

Gambar desain mekanik quadcopter dirancang menggunakan software sketch up, seperti berikut:

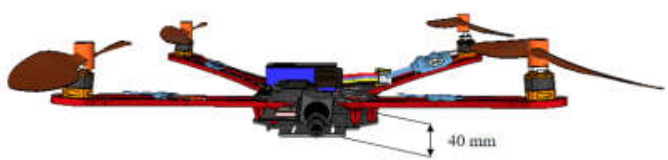

Gambar 17. Quadcopter Tampak Depan

Quadcopter memiliki spesifikasi yaitu berbentuk 4 lengan simetris masing-masing memiliki motor dan propeller. Berat keseluruhan kurang dari 3500 gram. Ketinggian terbang mencapai 9-meter dari permukaan tanah. Durasi sekali mengudara tergantung kapasitas sumber tenaga yang dipakai sekitar 5 menit

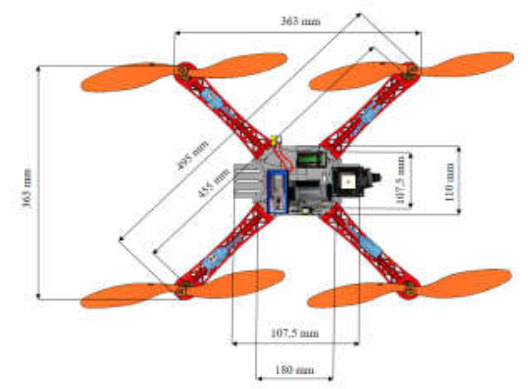

Gambar 18. Quadcopter Tampak Atas

. Sumber tenaga menggunakan baterai litium dengan kapasitas $2200 \mathrm{mAh}$. Dapat mengirimkan hasil tangkapan kamera dan telemetri realtime melalui Ground Control Station (GCS).

\section{Perancangan Perangkat Lunak}

\section{1) Mission Planner}

Berikut adalah tampilan dari perangkat lunak mission planner yang telah diatur dengan beberapa pengaturan. Baudrate di angka 115200. Di sudut kanan tampilan terdapat tombol port COM dropdown, kemudian dipilih AUTO atau port sesuai dengan board (APM 2.8) yang digunakan.

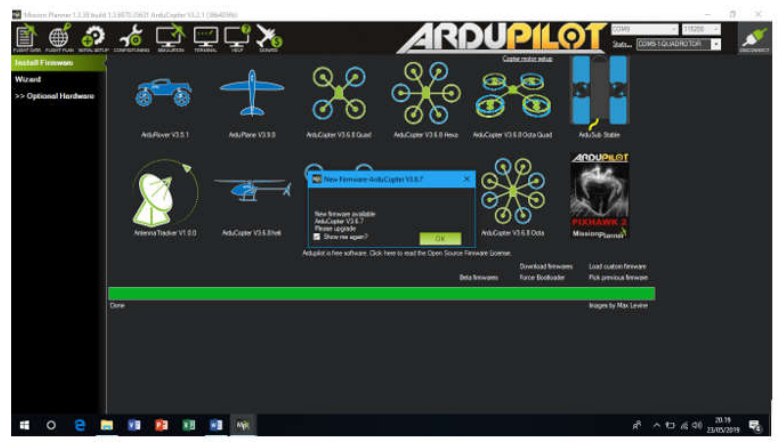

Gambar 19. Tampilan Mission Planner

\section{2) Remote Raspberry Pi 3}

Langkah-langkah remote raspberry pi 3 clientserver sebagai berikut: 
- Buka aplikasi Putty dan masukkan IP Address.

- Ketik "pi", password "raspberry" kemudian ketik "vncserver :2" pada terminal raspberry.

- Buka aplikasi VNC Viewer kemudian lakukan konfigurasi seperti pada Gambar 24.

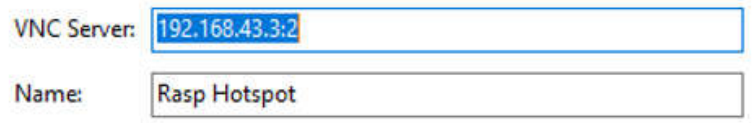

Gambar 20. Konfigurasi VNC Viewer

\section{HASIL DAN PEMbahasan}

Pengujian dimaksudkan untuk mengetahui fungsi setiap bagian sistem, sehingga layak diterapkan dalam sistem. Pengujian keseluruhan dimaksudkan untuk menguji kehandalan sistem terhadap kesalahan. Pembahasan setiap pengujian dibahas pada penjelasan berikut ini.

\section{A. Pengujian Perangkat Keras}

Berikut merupakan hasil dari pengujian perangkat keras dan mekanik quadcopter.

\section{1) Pengujian Remote Control}

Kemampuan RC dalam mengendalikan quadcopter dicoba menggunakan mekanisme pada blok diagram di bawah ini.

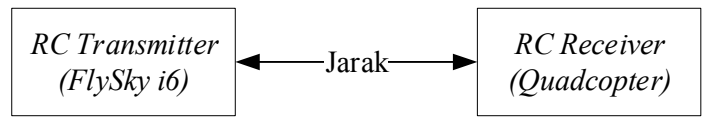

Gambar 21. Blok Diagram Pengujian Jarak Jangkauan RC

Dari hasil pengujian didapatkan hasil bahwa RC maksimal dapat mengendalikan sejauh 200 meter. Peningkatan kemampuan RC dapat dilakukan dengan menggunakan baterai yang memiliki daya besar, karena akan mempengaruhi daya jangkau dari RC.

\section{2) Pengujian Motor}

Pengaturan RPM pada gerak quadcopter dilakukan untuk mengetahui putaran dari motor, percobaan menggunakan tachometer. Cepat atau lambatnya pergerakan quadcopter dipengaruhi oleh pengaturan PWMnya. Cara yang dilakukan adalah membandingkan pemberian pulsa pada RC dengan kecepatan putaran motor.

Hasil pengukuran sesuai dengan table 1 didapatkan hubungan antara pulsa RC dengan kecepatan putaran motor bersifat linier. Jika pulsa $\mathrm{RC}$ dinaikkan, maka putaran motor juga akan meningkat.
Tabel 1 Pengukuran Pulsa RC dengan RPM Motor Brushless

\begin{tabular}{|c|c|c|c|c|c|}
\hline \multirow{3}{*}{ Percobaan } & \multirow{2}{*}{$\begin{array}{c}\text { Pulsa } \\
\text { RC } \\
\text { (\%) }\end{array}$} & \multicolumn{4}{|c|}{$\begin{array}{c}\text { Putaran Motor } \\
\text { (RPM) }\end{array}$} \\
\cline { 2 - 6 } & M 1 & M 2 & M 3 & M 4 \\
\hline \multirow{4}{*}{1} & 0 & 0 & 0 & 0 & 0 \\
\cline { 2 - 6 } & 25 & 3234,0 & 3202,0 & 3042,0 & 3151,8 \\
\cline { 2 - 6 } & 50 & 4629,2 & 4874,8 & 4556,6 & 4962,0 \\
\cline { 2 - 6 } & 75 & 8670,0 & 8758,2 & 8736,0 & 8820,0 \\
\cline { 2 - 6 } & 100 & 9427,8 & 9366,0 & 9180,0 & 9230,4 \\
\hline \multirow{4}{*}{2} & 0 & 0 & 0 & 0 & 0 \\
\cline { 2 - 6 } & 25 & 3778,0 & 3362,7 & 3414,8 & 3106,8 \\
\cline { 2 - 6 } & 50 & 4774,6 & 4745,8 & 4136,4 & 4180,2 \\
\cline { 2 - 6 } & 75 & 8688,0 & 8998,2 & 8880,6 & 8849,4 \\
\cline { 2 - 6 } & 100 & 9946,8 & 9558,0 & 9480,0 & 9386,4 \\
\hline
\end{tabular}

Saat pulsa pada RC dinaikan sebesar 25\% maka rata-rata kecepatan putaran motor bernilai 3414,8 RPM untuk motor1, 3268,7 RPM untuk motor2, 3242,3 RPM untuk motor3 dan 3283,8 RPM untuk motor4. Ketika pulsa pada RC dinaikan sebesar $50 \%$ maka rata-rata kecepatan putaran motor semakin meningkat dari sebelumnya, hasil dari pengukuran motor1 bernilai 4772,9 RPM, motor2 bernilai 4686,9 RPM, motor3 bernilai 4345,8 RPM dan motor4 bernilai 4545,3 RPM.

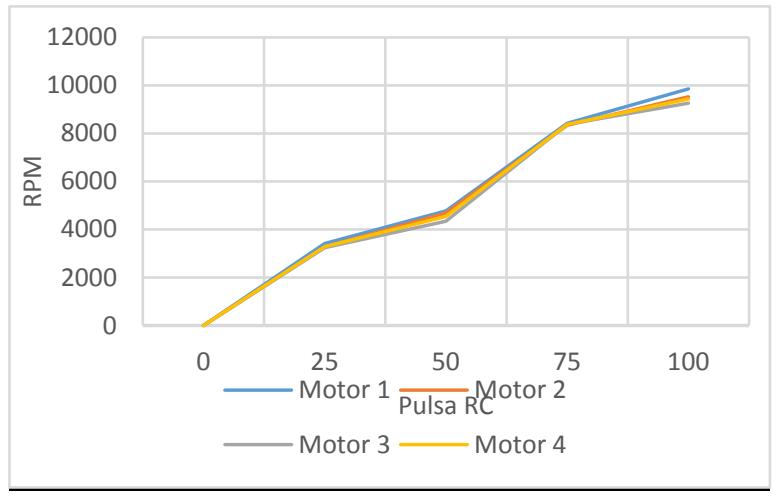

Gambar 22. Grafik Perbandingan Putaran Motor

Dari grafik di atas dapat disimpulkan bahwa rata-rata kecepatan putaran antara motor1, motor2, motor3, dan motor4 tidak terjadi selisih yang terlalu tinggi sehingga hal ini sangat baik untuk keseimbangan quadcopter saat terbang.

\section{3) Pengujian Gerak Quadcopter}

Terdapat beberapa Gerakan yang mungkin dilakukan oleh quadcopter, yaitu gerak naik dan turun, belok kanan dan kiri, memutar arah kanan dan kiri. Dengan pengujian gerak ini akan diketahui respon motor terhadap perintah yang diberikan.

Dari Tabel 2 diperoleh data respon motor terhadap kondisi quadcopter sesuai seperti pada Gambar 2. Hal ini ditunjukkan pada saat kondisi quadcopter mulai naik, motor akan memberikan respon yang sama 
Tabel 2 Pengukuran Respon Motor Terhadap Kondisi Quadcopter

\begin{tabular}{|l|l|l|l|l|l|}
\hline \multirow{3}{*}{ Pengujian } & Kondisi & \multicolumn{4}{|l|}{ Respon Motor } \\
\cline { 3 - 6 } & Quadcopter & M 1 & M 2 & M 3 & M 4 \\
\hline \multirow{5}{*}{1} & Naik & Cepat & Cepat & Cepat & Cepat \\
\cline { 2 - 6 } & Maju & Pelan & Cepat & Pelan & Cepat \\
\cline { 2 - 6 } & Mundur & Cepat & Pelan & Cepat & Pelan \\
\cline { 2 - 6 } & Kanan & Pelan & Cepat & Cepat & Pelan \\
\cline { 2 - 6 } & Kiri & Cepat & Pelan & Pelan & Cepat \\
\cline { 2 - 6 } & $\begin{array}{l}\text { Memutar } \\
\text { kanan }\end{array}$ & Cepat & Cepat & Pelan & Pelan \\
\cline { 2 - 6 } & $\begin{array}{l}\text { Memutar } \\
\text { kiri }\end{array}$ & Pelan & Pelan & Cepat & Cepat \\
\hline \multirow{5}{*}{2} & Naik & Cepat & Cepat & Cepat & Cepat \\
\cline { 2 - 6 } Maju & Pelan & Cepat & Pelan & Cepat \\
\cline { 2 - 6 } & Mundur & Cepat & Pelan & Cepat & Pelan \\
\cline { 2 - 6 } & Kanan & Pelan & Cepat & Cepat & Pelan \\
\cline { 2 - 6 } & Kiri & Cepat & Pelan & Pelan & Cepat \\
\cline { 2 - 6 } & $\begin{array}{l}\text { Memutar } \\
\text { kanan }\end{array}$ & Cepat & Cepat & Pelan & Pelan \\
\cline { 2 - 6 } & $\begin{array}{l}\text { Memutar } \\
\text { kiri }\end{array}$ & Pelan & Pelan & Cepat & Cepat \\
\hline
\end{tabular}

. Hasil ini menunjukkan kecepatan motor dapat dikendalikan dengan menggunakan stik RC yang digeser. Pengujian ini dilakukan untuk memastikan bahwa quadcopter dapat dikendalikan dengan baik menggunakan RC sesuai dengan posisi yang diinginkan.

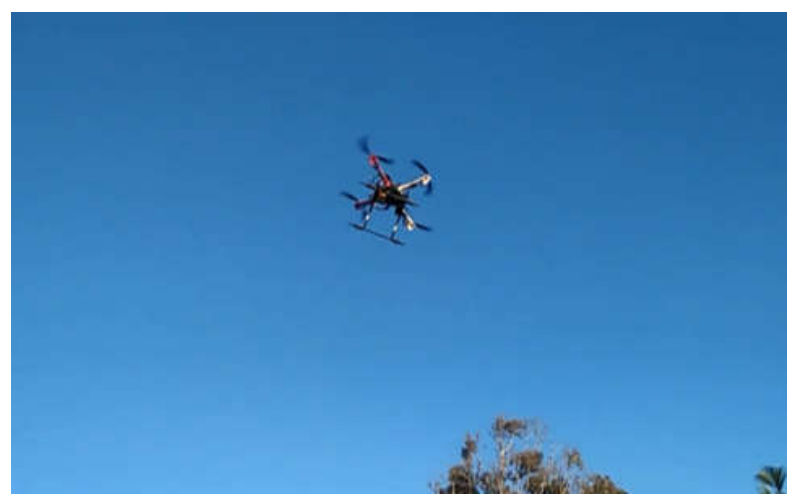

Gambar 23. Pengujian Gerak Quadcopter

\section{4) Pengujian Webcam}

Pengujian webcam terhadap foto manusia untuk mendeteksi objek didapatkan beberapa data. Manusia sebagai objek citra berdiri didepan webcam dengan jarak yang ditentukan. Webcam dihubungkan dengan Raspberry Pi 3. Webcam akan merekam foto yang kemudian akan diolah citranya oleh Raspberry $P i \quad 3$ untuk untuk menganalisa objek tersebut.

Dari hasil pengujian diperoleh data pendeteksian objek dengan jarak 1 hingga 10 meter. Persentase rata-rata keberhasilan pada rentang jarak 1 hingga 6-meter yaitu 100\%, pada jarak 7 hingga 8 -meter yaitu $80 \%$, pada jarak 9 hingga 10 -meter yaitu $60 \%$.
Tabel 3 Deteksi Objek Menggunakan webcam

\begin{tabular}{|c|c|c|c|c|c|}
\hline \multirow{2}{*}{ Jarak (m) } & \multicolumn{5}{|c|}{ Pengujian ke- } \\
\cline { 2 - 6 } & $\mathbf{1}$ & $\mathbf{2}$ & $\mathbf{3}$ & $\mathbf{4}$ & $\mathbf{5}$ \\
\hline 1 & $\sqrt{ }$ & $\sqrt{ }$ & $\sqrt{ }$ & $\sqrt{ }$ & $\sqrt{ }$ \\
\hline 2 & $\sqrt{ }$ & $\sqrt{ }$ & $\sqrt{ }$ & $\sqrt{ }$ & $\sqrt{ }$ \\
\hline 3 & $\sqrt{ }$ & $\sqrt{ }$ & $\sqrt{ }$ & $\sqrt{ }$ & $\sqrt{ }$ \\
\hline 4 & $\sqrt{ }$ & $\sqrt{ }$ & $\sqrt{ }$ & $\sqrt{ }$ & $\sqrt{ }$ \\
\hline 5 & $\sqrt{ }$ & $\sqrt{ }$ & $\sqrt{ }$ & $\sqrt{ }$ & $\sqrt{ }$ \\
\hline
\end{tabular}

Pengujian pendeteksian objek menggunakan webcam Logitech 310 sangat terpengaruh oleh jarak, intensitas cahaya dan frame per second (FPS).

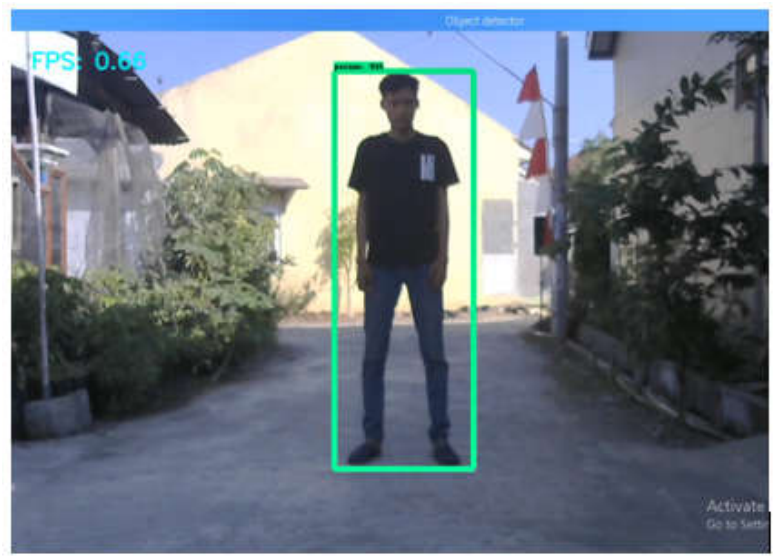

Gambar 24. Deteksi Objek

\section{B. Pengujian Perangkat Lunak}

\section{1) Pengujian Firmware ArduPilot Mega (APM)}

Pengujian firmware pada $A P M$ bertujuan untuk memastikan bahwa firmware untuk quadcopter telah berhasil di-upload pada board. Pengujian dilakukan dengan menghubungkan APM ke GCS/laptop yang menampilkan software mission planner menggunakan kabel USB ataupun dengan telemetry. Pada pengujian ini menggunakan kabel USB sebagai koneksi dan pada laptop terbaca pada COM3 dengan baudrate 115200, sedangkan pengujian menggunakan telemetry sebagai koneksi dan pada laptop terbaca COM4 dengan baudrate 57600 .

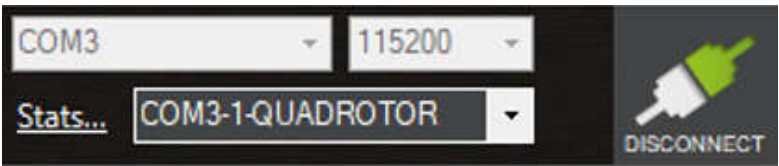

Gambar 25. Koneksi APM Menggunakan Kabel USB

Dari hasil pengujian firmware pada APM dapat disimpulkan bahwa firmware telah berhasil diupload ke board. Hal ini diketahui melalui status yang muncul setelah APM dihubungkan dengan software mission planner. Jika sistem operasi yang ter-install pada laptop merupakan windows 10 
maka baudrate akan otomatis menyesuaikan koneksi menggunakan kabel USB atau telemetry.

Saat ini firmware yang terdapat pada APM adalah ArduCopter versi 3.6.10 yang dapat dilihat pada Gambar 26.

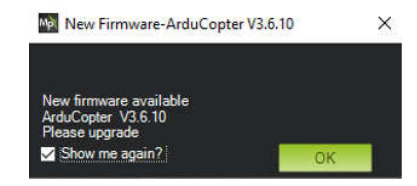

Gambar 26. Firmware APM

\section{2) Pengujian GPS Module}

Pengujian bertujuan untuk mengetahui kemampuan GPS module dalam menangkap sinyal satelit dan melakukan penguncian lokasi. Pengujian dilakukan di dalam ruangan dan di luar ruangan.

Tabel 4. Pengujian GPS Modul

\begin{tabular}{|c|l|c|c|}
\hline No & \multicolumn{1}{|c|}{ Lokasi } & Jumlah Satelit & Status \\
\hline 1 & Dalam ruangan & 1 & No Fix \\
\hline 2 & Dalam ruangan & 1 & No Fix \\
\hline 3 & Luar ruangan & 3 & 3D Fix \\
\hline 4 & Luar ruangan & 3 & 3D Fix \\
\hline 5 & Luar ruangan & 3 & 3D Fix \\
\hline
\end{tabular}

Dari hasil pengujian GPS module dapat disimpulkan bahwa ketika melakukan pengujian di dalam ruangan GPS hanya dapat menangkap satelit senilai 1, sedangkan ketika melakukan pengujian di luar ruangan GPS dapat menangkap satelit lebih baik yaitu mencapai nilai 3. Nilai GPS harus mencapai 3 satelit sebagai syarat minimum agar GPS dapat terkunci. Untuk mengetahui status GPS dapat dilihat pada tampilan HUD pada aplikasi mission planner dengan penjelasan sebagai berikut:

- Gpsstatus, menunjukkan nilai satelit yang ditangkap oleh GPS module.

- GPS: (keterangan), menunjukkan status GPS yakni "3D Fix" mengindikasikan bahwa GPS sudah terkunci, dan "Not Fix" menunjukkan bahwa GPS belum terkunci.

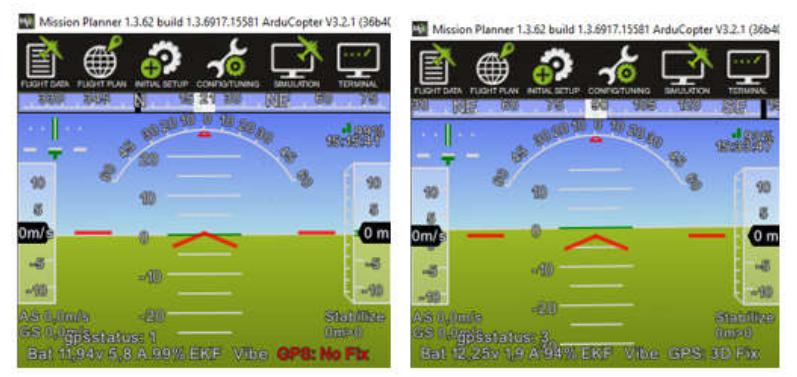

Gambar 27. Status Pengujian Modul GPS

3) Pengujian Telemetry
Telemetry digunakan quadcopter untuk memberikan informasi ke user. Pengujian dilakukan dengan cara menghubungkan antara

telemetry yang berada pada quadcopter dengan telemetry yang berada di laptop (user).

Tabel 5 Pengujian Kekuatan Sinyal Telemetri

\begin{tabular}{|c|c|c|}
\hline No & $\begin{array}{c}\text { Jarak Antar } \\
\text { Telemetry (m) }\end{array}$ & $\begin{array}{c}\text { Kekuatan Sinyal } \\
\text { Telemetry (\%) }\end{array}$ \\
\hline 1 & 0 & 100 \\
\hline 2 & 5 & 100 \\
\hline 3 & 15 & 97 \\
\hline 4 & 25 & 83 \\
\hline 5 & 45 & 37 \\
\hline
\end{tabular}

Dari hasil pengujian telemetry dapat disimpulkan bahwa telemetry dapat terhubung dengan baik antara telemetry pada quadcopter dengan telemetry pada laptop sebagai GCS dengan jarak maksimum 37 meter, jika lebih dari itu maka koneksi akan hilang. Jarak antar telemetry sangat mempengaruhi kekuatan sinyal.

\section{Pengujian Deteksi Objek}

Seluruh sistem berjalan dengan baik sesuai dengan apa yang sudah dirancang dan direncanakan. Pengujian keseluruhan juga dapat digunakan untuk mengetahui kendala pada quadcopter.

Tabel 6. Pengujian Quadcopter Deteksi Objek

\begin{tabular}{|c|c|c|c|c|}
\hline $\begin{array}{c}\text { Pengujian } \\
\text { ke- }\end{array}$ & $\begin{array}{c}\text { Satelit } \\
\text { GPS }\end{array}$ & $\begin{array}{c}\text { Sinyal } \\
\text { Telemetry }\end{array}$ & $\begin{array}{c}\text { Ketinggian } \\
\text { (m) }\end{array}$ & $\begin{array}{c}\text { Deteksi } \\
\text { Objek }\end{array}$ \\
\hline 1 & 3 & $99 \%$ & 2 & Terdeteksi \\
\hline 2 & 3 & $98 \%$ & 3 & Terdeteksi \\
\hline 3 & 3 & $99 \%$ & 2 & Terdeteksi \\
\hline
\end{tabular}

Dari hasil pengujian quadcopter deteksi objek pada Tabel 6 diperoleh analisa sebagai berikut:

a) Respon pergerakan quadcopter terhadap perintah dari remote control dapat bekerja dengan baik yaitu pitch, roll, dan yaw.

b) Kecepatan putaran motor berfungsi sesuai perintah throttle dari remote control.

c) Quadcopter dapat mendeteksi objek dengan rata-rata ketinggian 2 meter.

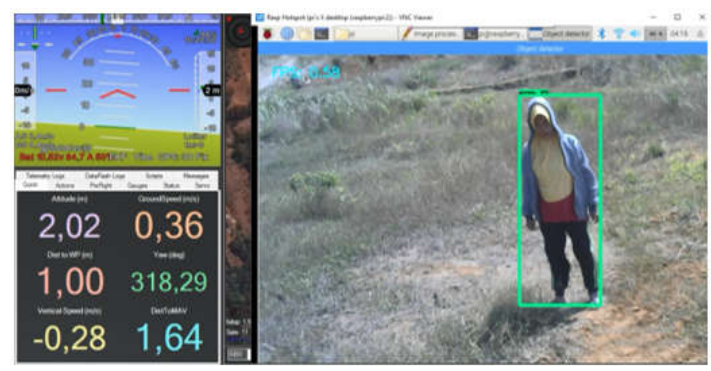

Gambar 28. Quadcopter Deteksi Objek 


\section{KESIMPULAN}

Paper ini memiliki output untuk memberikan perspektif yang berbeda dalam pendeteksian objek pada daerah menggunakan metode image processing. Dari hasil pengujian, integrasi seluruh komponen memberikan data bahwa jarak maksimal pengiriman data ke ground control station 45meter dan kamera dapat mendeteksi objek dengan jarak 1 sampai 6 meter. Dengan hasil ini diharapkan bisa memberikan kontribusi terhadap metode penanganan bencana dengan mapping daerah bencananya. Pada penelitian selanjutnya, penggunaan motor dan pengendali yang lebih baik dapat memberikan hasil yang lebih optimal. Selain itu, system komunikasi dengan satelit juga ditingkatkan interkoneksinya.

\section{DAfTAR PUStaka}

[1] Indra Krista, Elang Derdian M, ST, MT, Dr. Dedy Suryadi, ST, MT. "Rancang Bangun Robot Terbang Model Tricopter Menggunakan STM32F". Fakultas Teknik. Universitas Tanjungpura. Pontianak.

[2] Disha Amruthal Gandhi, Munmun Ghosal (2018). Novel Low-Cost Quadcopter for Surveillance Application. International Conference on Inventive Research in Computing Applications (ICIRCA). 412414.

[3] Ardian Firsta Harista, Satyo Nuryadi. 2018. "Sistem Navigasi Quadcopter dan Pemantauan Udara". Jurnal Tekno Sains Seri Teknik Elektro. Vol.1, No.1.

[4] Mitsuru Enomoto, Yoshio Yamamoto. 2015. Modelling, simulation and navigation experiments of Unmanned Aerial Vehicle. IEEE International conference on Mechatronics and Automation (ICMA).

[5] Risha Anugerah Nenu Lema. 2016. "Flight Controller pada Sistem Quadcopter Menggunakan Sensor IMU (Inertial Measurement Unit) Berbasis Mikrokontroler ATmega 2560". Fakultas Sains dan Teknologi. Universitas Sanata Dharma. Yogyakarta

[6] Chang-Chi Lee, Gwo-Jen Chiou, Jeng-Yue Chen, Yao-Chun Tung, Fuh-Shyang Juang. 2017. Implementation of a novel brushless DC motor controller. $12^{\text {th }}$ Conference on
Industrial Electronics and Applications (ICIEA). 1641-1645.

[7] Hardy Samuel Saroinsong, Vecky C. Poekoel, Pinrolinvic D.K Manembu. 2018. "Rancang Bangun Wahana Pesawat Tanpa Awak (Fixed Wing) Berbasis Ardupilot". Jurnal Teknik Elektro dan Komputer. Vol.7, No.1.

[8] Ilya. S. Shipunov, Konstantin S. Voevodskiy, Yuri F. Katorin, Yuri A. Gatchin. 2019. Trusted Transport Telemetry by Using Distributed Databases. IEEE Conference of Russian Young Researchers in Electrical and Electronic Engineering. 344-347.

[9] Tan Viet Anh Truong, Gautier Hattenberger, Catherine R. Nadaud. 2013. The cooperation between UAV Using a Mission Planner. IEEE Conference Paper.

[10] Thiago Rodrigo F.C, Iury V. de Bessa, Lucas C. Cordeiro. 2017. Planning and Evaluation of UAV Mission Planner for Intralogistics Problems. Brazilian Symposium on Computing System Engineering.

[11] U Bharavi, Rao M. Sukesh. 2017. Design and Development of GSM and GPS tracking module. $2^{\text {nd }}$ IEEE International Conference on Recent Trends in Electronics, Information and Communication Technology. 283-288.

[12] Daniel Ng C. L, Suhaila Isaak, Yusmeeraz Yusof. 2019. Machine Vision based smart parking system using IoT. Jurnal Telkomnika Vol 17(4). 2098-2106.

[13] Rony Baskoro Lukito, Cahya Lukito. 2019. Development of IoT at Hydroponic Syatem Using Raspberry Pi. Jurnal Telkomnika Vol 17(2). 897-906.

[14] Dwi Sudarno Putra, Donny Fernandez, Wagino. 2018. Optimization of Digital Image Processing Method to Improve Smoke Opacity Meter Accuracy. International Journal on Informatics Visualization. Vol 2(2). 88-91.

[15] Devita Nitiamijaya. 2017. “Aplikasi Webcam Sebagai Pengidentifikasi dan Pengolah Citra Warna Foto dengan Program Python". Teknik Elektro. Politeknik Negeri Jakarta. Jakarta.

[16] Rizky Dwi Novyantika. 2018. "Deteksi Tanda Nomor Kendaraan Bermotor pada Media Streaming dengan Algoritma Convolutional Neural Network Menggunakan TensorFlow". Fakultas 
Matematika dan Ilmu Pengetahuan Alam. Universitas Islam Indonesia. Yogyakarta.

\section{Biodata Penulis}

Arif Ainur Rafiq, Staf pengajar di Jurusan Teknik Elektronika, Politeknik Negeri Cilacap. Menyelesaikan Sarjana di Universitas Islam Indonesia, Yogyakarta tahun 2005. Program Magister dari Universitas Indonesia dan Universite de Bretagne Occidentale, Brest Prancis melalui Program Double Degree Indonesia Perancis, selesai tahnu 2011. Bidang riset yang ditekuni adalah instrumentasi, sensor transduser, devais elektronika, IoT dan embedded system.

Sugeng Dwi Riyanto, Staf pengajar di Jurusan Teknik Elektronika, Politeknik Negeri Cilacap.
Menyelesaikan Sarjana dari Universitas Negeri Malang tahun 2006. Program Magister dari Institut Teknologi 10 November Surabaya tahun 2012. Bidang risetnya adalah elektronika.

Bagas Dwi Aprilas, programmer bidang elektronika dan pemerhati quadcopter.

Rizki Priya Pratama, Staf Pengajar di Program Studi Teknik Mekatronika, Politeknik Kota Malang. Sarjana Teknik Elektro, Universitas Brawijaya Malang. Program Magister dari Universitas Indonesia dan Universite Anger, Perancis melalui Program Double Degree Indonesia Perancis, selesai tahnu 2011. Bidang riset yaitu programming dan embedded system. 